(C) Опришко В. І., Носівець Д. С., 2017

\author{
Опришко Валентина Іванівна, \\ Носівець Дмитро Сергійович \\ Державний заклад «Дніпропетровська медична академія \\ Міністерства охорони здоров'я України»

\section{ПИТАННЯ ПІДГОТОВКИ СТУДЕНТІВ ПРИ ВИКЛАДАННІ ПРЕДМЕТУ «ФАРМАКОЛОГІЯ»}

Фармакологія - ие один з основних предметів, який займає значне місие в навчальному прочесі студентів II та III курсів медичних $i$ стоматологічних факультетів та засновується на базовому вивчені студентом основних теоретичних дисииплін. У сукупності ияі дисципліни дають можливість об'єднати і сформувати в уявленні майбутнього лікаря різну за обсягом $i$ складну для сприйняття $i$ запам'ятовування інформацію, яка дуже важлива в аспекті клінічного $i$ професійного становлення майбутнього фахівия. Авторами на підставі власного досвіду висвітлені особливості технологічних та теоретичних аспектів викладання предмету «фармакологія» при підготовиі студентів вищих навчальних медичних закладів. Проаналізовані особливості проведення практичних занять, самостійної роботи студентів та організації навчального процесу на кафедрі фармакології та клінічної фармакології. Встановлено, що прийняті заходи сприяють підвищенню зачікавленості у навчанні, узагальненню уяви студентів про найбільш складні питання предмету «фармакологія» як дисиипліни, оптимальної організачії їх самостійної аудиторної та позааудиторної роботи.

Ключові слова: фармакологія, організачія навчального прочесу, підготовка студентів.

Проблема, їі зв'язок із важливими науковими чи практичними завданнями. Свропейська інтеграція України до країн СС викликала необхідність у відповідних змінах системи освіти. Зокрема, розширення ринку медичних послуг та висока конкуренція на ньому викликає необхідність у якісній підготовці майбутніх фахівців цієї галузі.

Значне місце в навчальному процесі студентів II та III курсів медичних та стоматологічних факультетів займає предмет «фармакологія» [1]. Аудиторна та позааудиторна робота при вивченні цього предмету заснована на базовому освоєнні студентом основних 
теоретичних дисциплін - фізіологія, анатомія, патологічна фізіологія та інші. Ці дисципліни дають можливість об'єднати і сформувати в уявленні майбутнього лікаря різну за обсягом i складну для сприйняття і запам'ятовування інформацію щодо фармакокінетики, фармакодинаміки, фізичних i хімічних властивостей лікарських засобів, отримання лікарської сировини та їх дії на живий організм в аспекті клінічної і професійної діяльності майбутнього фахівця [2-5].

Ціль статті - на підставі власного досвіду висвітлити питання підготовки студентів при вивченні предмету «фармакологія» на кафедрі фармакології та клінічної фармакології ДЗ «Дніпропетровська медична академія МОЗ України».

Виклад основного матеріалу, обгрунтування результатів дослідження. При плануванні самостійної роботи студентів нами приділяється велика увага таким особливостям навчального процесу, як залежність дії лікарських речовин від їх хімічної будови, особливості фармакокінетики i фармакодинаміки препаратів рослинного та синтетичного походження [6-8]. При цьому певна увага повинна звертатися і приділятися на особливості вибору найбільш доцільної медикаментозної форми лікарської речовини, що визначає найкращу, максимальну біодоступність головної базової речовини [9].

Оптимізація самостійної роботи студентів, на наш погляд, можлива і досягається шляхом формування значної кількості тестових завдань різної форми та рівня складності з різних розділів предмету «фармакологія». При цьому значна кількість тестових завдань нами оформляється зі спеціальними умовами, описом клінічних i фармакологічних ситуацій, що сприяє позитивній мотивації студентів і формуванню певної психологічної налаштованості при підготовці до тематичних занять 3 предмету «фармакологія» і освоєння майбутньої професії [10; 11].

На практичних заняттях зі студентами розбираються питання, які зачіпають різні аспекти тематичного уроку - вихідний контроль знань, основний рівень знань і заключний контроль. Необхідною умовою при проведенні практичного заняття $є$ об'єднання основних $\mathrm{i}$ найбільш складних питань загальної та спеціальної фармакології $[1 ; 2 ; 9 ; 11]$.

Важливе значення мають експериментальні дослідження, які ми включаємо в склад практичних занять [11]. Ці заняття полягають в об'єднанні експериментів фармацевтичного та фармакологічного характеру, на яких вивчаються оптимальна лікарська форма і шляхи введення лікарської речовини, що забезпечують максимальний фармакологічний результат, токсичність препаратів, вплив на різні фізіологічні системи організму і т.д. До елементів самостійної роботи 
студентів відноситься також рішення комп'ютерних задач контрольного та навчального характеру [8; 9].

На кафедрі фармакології та клінічної фармакології ДЗ «ДМА MO3 України» для ефективного забезпечення студентів навчальним матеріалом працює інтернет-сайт, на якому розміщені тематичні плани i завдання за всіма тематичними розділами дисципліни «фармакологія» [2;12]. Обов'язковим елементом роботи $\epsilon$ також освоєння принципів лікарської рецептури, чому приділяється увага на кожному практичному занятті даних предметів протягом усього періоду навчання студентів [2; 5].

Позааудиторна робота студентів також грунтується на інтегрованому підході до вивчення предмету «фармакологія» в тісному зв'язку 3 іншими базовими i фармацевтичними дисциплінами. До складу позааудиторної роботи студентів входить підготовка до кожного практичного заняття згідно 3 розробленими та опублікованими методичними рекомендаціями [4; 6-8]. Результати такої роботи перевіряються і оцінюються викладачем на відповідному тематичному занятті. Крім того, студентам пропонується спеціальна тематика самостійних занять 3 найбільш актуальних i важливих питань, а також 3 додаткових питань курсу «фармакологія». Також заохочується робота студентів 3 літературою монографічного та поточного характеру, а також даними інтернет-ресурсів. Результати позааудиторної роботи оформлюються студентами у вигляді рефератів, доповідей, а найкращі з них - виносяться на обговорення в групи студентського наукового товариства кафедри $[3 ; 5 ; 9]$. Проведення занять студентського наукового товариства забезпечується таким чином, що композиція доповідей обумовлює висвітлення питань не лише щодо фармакокінетики i фармакодинаміки, а також освітлюються питання фармакогностичного i фармакохімічного характеру, що обумовлює обговорення особливостей механізму дії і використання лікарських речовин $[2 ; 3]$.

Висновки, перспективи. Таким чином, наш досвід викладання та технологічні і теоретичні заходи щодо підготовки студентів при вивченні предмету «фармакологія» сприяють підвищенню зацікавленості до навчання, узагальненню уявлення студентів про найбільш важливі питання цієї дисципліни i призводить до оптимальної організації їх самостійної аудиторної та позааудиторної роботи, що важливо для високого професійного формування майбутнього лікаря та особистості.

\section{Література}

1. Опрышко В. И. Современные подходы к модернизации структуры и качества преподавания (на примере учебных курсов «фармакология» и «клиническая фармакология») / В. И. Опрышко, 
Д. С. Носивец // IX Міжнар. конф. «Стратегія якості у промисловості і освіті» (31.05-7.06.2013 р., Варна, Болгарія): Матеріали. У 3-х томах. Т. 1. Упорядники: Хохлова Т. С., Х Хохлов В. О., Ступак Ю. О. Дніпропетровськ-Варна, 2013. - С. 243-245.

2. Опрышко В. И. Методическое обеспечение и организация учебного процесса при подготовке студентов на кафедре фармакологии и клинической фармакологии / В. И. Опрышко, Д. С. Носивец // Мат. XXI Міжнар. наук.-метод. конф. «Управління якістю підготовки фахівців». - Одеса, 2016. - Ч. 2. - С. 166-167.

3. Опрышко В. И. Организация педагогического процесса при изучении предметов «фармакология» и «клиническая фармакология» / В. И. Опрышко, Д. С. Носивец // Філософсько-гуманітарні читання: зб. наук. праць / Відп. ред. О.В.Добридень; Редагування В. Ю. Кравченко, А. І. Нікітенко. - Дніпропетровськ: ДЗ «ДМА», 2016. - C. 234-237.

4. Опрышко В. И. Творческий потенциал студентов как основа повышения качества изучения предметов «фармакология» и «клиническая фармакология» / В. И. Опрышко, Д. С. Носивец // Актуальні питання освіти і науки: зб. наук. ст., мат. наук.-практ. конф., 23-24 жовт. 2013 р. / Академія внутрішніх військ МВС України. - Х. : ХОГОКЗ, 2013. - С. 195-198.

5. Опрышко В. И. Преподавание предметов «фармакология» и «клиническая фармакология» в аспекте качества медицинского образования / В. И. Опрышко, Д. С. Носивец // От качества медицинского образования - к качеству медицинской помощи. Мат. III науч.-практ. конф. с международным участием: Изд. ГБОУ ВПО УГМУ Минздрава России, 2015. - С. 49-52.

6. Опрышко В. И. Самостоятельная работа студентов при изучении предметов «фармакология» и «клиническая фармакология» в аспекте профессиональной подготовки врача / В. И. Опрышко, Д. С. Носивец // Актуальні питання лінгвістики, професійної лінгводидактики, психології і педагогіки вищої школи: збірник статей II Всеукраїнської науково-практичної конференції 3 міжнародною участю (м. Полтава, 8-9 червня 2017 року). - Полтава: Вид-во «Астрая», 2017. - С. 184-187.

7. Опрышко В. И. Опыт организации самостоятельной работы студентов при изучении предметов «фармакология» и «клиническая фармакология» / В. И. Опрышко, Д. С. Носивец // Філософськогуманітарні читання : зб. наук. праць міжнар. наук.-практ. конф. «Актуальні проблеми та перспективи розвитку сучасного соціальногуманітарного знання». - Дніпропетровськ, 2015. - № 2. - С. 99-102.

8. Опришко В. І. Самостійна робота студентів при вивчені предметів «фармакологія» та «клінічна фармакологіія» в аспекті 


\section{Збірник наукових статей}

професійної компетентності майбутнього лікаря / В. І. Опришко, Д. С. Носівець // Актуальні питання освіти і науки : зб. наук. ст., матеріали IV міжнар. наук.- практ. конф., 10-11 листоп. 2016 р. / Харківський національний економічний університет ім. Семена Кузнеця. - Х. : ХОГОКЗ, 2016. - С. 325-329.

9. Опрышко В. И. Педагогические аспекты проблемноориентированного обучения при изучении предметов «фармакология» и «клиническая фармакология» / В. И. Опрышко, Д. С. Носивец // Впровадження інноваційних технологій в медичну освіту: проблемноорієнтовне навчання та віртуальні пацієнти: Мат. Всеукр. наук.-метод. відеоконф. (12-13 листопада 2015 року, м. Запоріжжя). - Запоріжжя, 2015. - C. $120-122$.

10. Опрышко В. И. Технологические и теоретические аспекты подготовки студентов при изучении предмета “фармакология" / В. И. Опрышко, Д. С. Носивец // Актуальні питання освіти і науки: Зб. наук. ст., матеріали III міжнар. наук.-практ. конф., 10-11 листоп. 2015 р. / Національна академія Національної гвардії України. - Х. : ХОГОКЗ, 2015. - С. 154-158.

11. Опрышко В. И. Некоторые аспекты проблемноориентированного обучения при изучении предметов «фармакология» и «клиническая фармакология» / В. И. Опрышко, Д. С. Носивец // Впровадження інноваційних технологій в медичну освіту: проблемноорієнтоване навчання та віртуальні пацієнти: Мат. всеукр. наук.-метод. відеоконф. 3 міжнар. участю (22 квітня 2015 р., м. Запоріжжя). Запоріжжя, 2015. - С. 118-120.

12. Опришко В. І. Використання телекомунікаційних систем при вивчені предметів «фармакологія» та «клінічна фармакологія» / В. І. Опришко, Д. С. Носівець // Сучасні підходи до вищої медичної освіти в Україні (з дистанційним під'єднанням ВМ(Ф)НЗ України за допомогою відеоконференц-зв'язку): матеріали XIV Всеукр. наук.практ. конф. 3 міжнар. участю, присвяченої 60-річчю ТДМУ (Тернопіль, 18-19 трав. 2017 р.). - Тернопіль : ТДМУ, 2017. - Т. 2. C. 106-107.

Валентина Опрышко, подготовки студентов «фармакология».

Фармакология - это один из основных предметов, который занимает важное место в учебном прочессе студентов II и III курсов медииинских и стоматологических факультетов и основывается на базовом изучении студентом основных теоретических дисииплин. $B$ своей совокупности эти дисииплинь дают возможность объединить и сформировать в представлении будущего врача разную по объему и сложную для восприятия и запоминания информаџию, которая очень 
важна в аспекте клинического и профессионального формирования будущего спеичилиста. Авторами статьи на основании собственного опыта освещень особенности технологических и теоретических аспектов преподавания предмета «фармакология» при подготовке студентов высших учебных медицинских заведений. Проанализированы особенности проведения практических занятий, самостоятельной работь студентов и организачии учебного прочесса на кафедре фармакологии и клинической фармакологии. Установлено, что описанные мероприятия способствуют повышению заинтересованности в обучении, обобщению представления студентов о наиболее сложных вопросах изучаемой дисциплины, оптимальной организации их самостоятельной аудиторной $u$ внеаудиторной работьл.

Ключевые слова: фармакология, организация учебного процесса, подготовка студентов.

Valentina Opryshko, Dmitriy Nosivets. The training of students in teaching the subject of "pharmacology».

Pharmacology is one of the main subjects, which occupies an important place in the educational process of students at levels II and III courses in medical and dental schools and is based on the baseline study by the student the basic theoretical disciplines. Collectively these disciplines provide an opportunity to combine and form in view of the future of the doctor is different in scope and difficult to understand and remember information that is very important in the aspect of clinical and professional formation of the future specialist. The authors on the basis of their own experience the peculiarities of the technological and theoretical aspects of teaching the subject of "pharmacology» for students of higher medical educational institutions. The features of the practical training, independent work of students and organization of educational process at the Department of pharmacology and clinical pharmacology. It is established that the described activities enhance interest in learning, the generalization of the views of students about the most difficult questions of the study subjects, the optimal organization of their independent classroom and extracurricular work.

Keywords: pharmacology, organization of the educational process, the training of students.

Інформація про авторів:

Стаття надійшла до редакційної колегії 26.09.2017

Опришко Валентина Іванівна - доктор медичних наук, професор, ДЗ «Дніпропетровська медична академія МОЗ України».

Носівець Дмитро Сергійович - кандидат медичних наук, асистент, Д3 «Дніпропетровська медична академія МОЗ України». 